\title{
Diasporic Archives and Hauntological Accretions
}

\author{
May Chew
}

DOI:10.15664/fcj.v19i0.2383

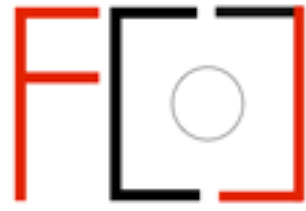

Frames Cinema Journal ISSN 2053-8812

Issue 19 (March 2022)

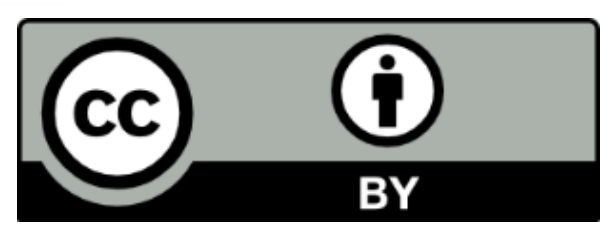


Frames Cinema Journal, Issue 19 (March 2022)

\section{Diasporic Archives and Hauntological Accretions}

May Chew

\section{Introduction}

Archives exclude as much as they include, eliminate as much as they preserve. The confluence of both increased technological access and social pressures have led to recent counter-archival explorations of and by communities long kept out of official archives. Centring on two participatory archival projects, Jacqueline Hoàng Nguyễn's The Making of An Archive (2014-present), and Regent Park Film Festival's Home Made Visible (2017-2019), this essay argues that diasporic archives can "densify" authoritative records, and allow us to think generatively about archival movements and accretions. Both of these projects focus predominantly on gathering and digitising archives from members of diasporic and racialised communities. Through public calls and workshops soliciting amateur archivists' personal and familial troves of still and moving images, these participatory archiving projects excavate and inscribe "minor," quotidian, and ephemeral records as a response to Canadian multiculturalism's many lacunae and imposed silences. The projects also capture the material traces of complex migration histories and transnational entanglements that exceed the limits of national archival narratives. In what follows, I approach diaspora - and diasporic archives - not (just) through rubrics of loss and obsolescence, but through the concept of hauntological thickening, which refers to the melancholies, disturbances, and traumas that diasporic subjects inherit and carry with them, as well as how these affects accrete and congeal in the media produced by their creators. Far from static, these archives are constantly in-transit, gathering and reverberating histories as they move across spatial and temporal registers. 
The first section of this paper focuses on the counter-archival impulses at work in The Making of An Archive (MoaA) and Home Made Visible (HMV) and considers how heteroglossic and mobile archives exceed the boundaries of nation. Next, the paper explores diasporic archives through the concept of hauntological accretion, and argues that these two projects intervene on authoritative archives by thickening the latter with occluded histories, dust, noise, grain, and other textural traces of spatial and temporal transfer. This is followed by an examination of how quotidian visual records offer hauntological refractions of official narratives, and become vehicles for complex imbrications of personal, familial, and national histories and discourses. Finally, the paper concludes with an exploration of how the archives engage audiences through affective and sensorial registers.

MoaA is an ongoing project by artist, Jacqueline Hoàng Nguyễn, focused on archives of migrants who identify as POC (People of Colour). ${ }^{1}$ The project was spurred both by the artist's encounter with the paucity of visual documents tracing the history of multiculturalism and immigration in official Canadian archives, as well as her perusal of photographic albums of her own father, who immigrated to Canada from Vietnam in $1974 .^{2}$ The project has organised workshops across Canada, to which participants are invited to bring their family albums for digitisation and to contribute personal and familial narratives that help contextualise these visual archives. HMV was a similar project by the Regent Park Film Festival, a community film festival in Toronto, which invited IBPOC (Indigenous, Black, People of Colour) participants across Canada to donate home videos for digitisation. ${ }^{3}$ Additionally, seven IBPOC artists were also commissioned to develop projects centred on the exploration of archives. ${ }^{4}$ Built around ideals of community engagement, HMV included a national tour across Canada, consisting of screenings of digitised home movies, workshops, and the presentation of artworks by the commissioned artists. Altogether, HMV garnered a total of 294 magnetic and analogue (videotape and film) items collected from 39 donors, which they then digitised. Donors were also 
interviewed, and some of their narratives were included along with their home movies. Altogether, there are over nine hours of donated footage, of which a portion has been made available on the HMV website, where users are able to view the digitised archives of fifteen families. ${ }^{5}$

While similar, these are not identical projects. Whereas the entire collection of digitised home movies garnered by HMV were acquired by York University Libraries, where they will be held in perpetuity in the Clara Thomas Archives \& Special Collection, the photographs for MoaA are part of a more amorphous and ongoing artist project. ${ }^{6}$ Further, while HMV also has a number of the digitised collections available on their website in a systematised yet incomplete archive, the MoaA website does not contain a publicly accessible archive. Nonetheless, both projects are mobilised around the stated importance of excavating and protecting the quotidian histories of minoritised communities across Canada, and recontextualising these histories for an expanded public imaginary.

\section{Counter-Archives}

HMV and MoaA are examples of counter-archives, or creative remonstrances against national archives shaped by longstanding settler colonial histories. ${ }^{7}$ The counter-archive, Brett Kashmere writes, "represents an incomplete and unstable repository, an entity to be contested and expanded through clandestine acts, a space of impermanence and play."8 Similarly, Paula Amad describes the counterarchive as a "challenge to the positivist archive's sacred myths of order, exhaustiveness, and objective

neutrality." Counter-archiving thus implies an insurgent action or hermeneutics that approaches archives as paradoxically structured around the very qualities they attempt to negate or repress: (im)permanence, (in)stability, (in)completeness. Crucially, in Kashmere's conceptualisation, the counter-archive is less about complete opposition to any official archive, than an invitation to directly engage official archives through creative experimentation, negotiation, and potential subversion. ${ }^{10}$ In 
this vein, HMV and MoaA do not renounce the nation so much as they exist in tension alongside it, and point to its inherent contradictions and intractabilities.

Considerations regarding these projects' in/direct relationship to nation are especially complex given that they are both funded by federal arts grants. ${ }^{11}$ One assumes that HMV in particular needed to be legible in specific ways to be granted the significant amount of Sesquicentennial federal funding that it received. Official recognition through a federal arts grant would seem to hinge on the project's demonstrated adherence to the aim of archival accommodation for the minoritised presence $-\mathrm{a}$ decipherable aim within the liberal multicultural model of inclusion catalysed around perpetual promises of minor reforms rather than structural overhauls. Strategic legibility can thus provide a vehicle for more complex and even potentially fugitive elements within the archive - those counterarchival threads inadvertently filed alongside more sanctioned artefacts and histories. Thus, while counter-archives can exist external to state support, they can also channel received state resources towards challenging the state's inviolability, including through focusing on histories and narratives typically excluded from institutional archives. Further, rather than being permanently housed in institutional settings, counter-archives can be enacted in more mobile and ephemeral contexts, including through digital platforms, community gatherings, workshops, performances, etc. These more flexible and informal configurations allow for capillary dispersions of archival knowledge back to communities. Relatedly, counter-archives often depend on alternate networks of care and relationality. The endurance of the records held by HMV and MoaA indicate how counter and amateur archives can bypass official archival structures and travel along divergent routes of care and stewardship, with family and community members often becoming inadvertent archivists whose labours enable the records' survival. 
Counter-archives emerge from particular technological, social, and political contexts. In her study of the history of amateur film, Patricia R. Zimmermann explains how the momentous convergence of consumer culture and the nuclear family gave rise to recognisable discursive and aesthetic forms in home videos from the 1950s-1960s. ${ }^{12}$ Amateur film can be considered counter-archival insofar as it falls outside the traditional ambit of institutional support and capture. Certainly, much of HMV's home movies, gathered between the 1960s to the mid-2000s, dovetail with the emergence of portable film cameras from the 1960s and video from the 1970s-80s, and waned with the inundation of digital selfimaging, which irrevocably altered the processes of personal and familial "archiving." Alongside this convergence of technological and social formations, the HMV's and MoaA's visual records were also produced in specific political and economic contexts. Much of these projects' still and moving images emerged from post-1960s Canada, an era marked by a shift in immigration policy, resultant demographic changes, and the inauguration of state multiculturalism. ${ }^{13}$ As counter-archival projects, HMV and MoaA call attention to the contradictions inherent in official state multiculturalism's public declarations and private erasures, echoing broader critiques of the ways in which state multiculturalism masks distinctly colonial and neoliberal imperatives through a façade of benevolence and inclusion. ${ }^{14}$ More specifically, both projects aim to rectify multiculturalism's lacunae and elisions by helping to safeguard minoritised archives.

In contextualising her contributions, HMV participant Stella Isaac describes the importance of inscribing experiences of Black families in Canada and making their presence visible to wider publics: "It's great to allow families the opportunity to revisit old footage, explore their history and share that. A lot of people don't think of Black people in Canada just existing. It's a great way to change the Canadian narrative." ${ }^{\prime 15}$ Another contributor from the Khmer-Krom community, an ethnic minority group from South Vietnam, recounts how their mother, Trinh Nha Truong, views their footage as a reminder that members of their community "live in 
Canada too." ${ }^{" 16}$ Likewise, Nguyễn's project through MoaA is explicitly mobilised around the need to preserve narratives that disclose the "complicated histories of migration." 17 These are histories that, along with the analogue and celluloid media on which they are carried, face obsolescence in the absence of institutional recognition and support. Nguyễn's aim is thus to create "a new archive that seeks to represent the fractured ideology of multiculturalism from the bottom up."18 Departing from multiculturalism as official state technology and discourse, then, this "new archive" is understood as the potential site for more contingent and complex articulations of multiculturalism as lived difference.

In Zimmermann's consideration of the ways in which amateur film prompts a rethinking of the archive, she points to how "the multiplication of practices, technologies, zones, and representations" can work to move us "beyond the repression of difference." 19 Further, these heteroglossic articulations can, among other things, serve "as a corrective to nationalised representational systems" and the models of homogeneity they promote. ${ }^{20}$ Zimmermann goes on to posit that amateur films pluralise national myths and narratives by "perform[ing] a form of psychic history-writing, a making legible of the invisible history of fantasies and social relations, a knitting of the local to the global." ${ }^{21}$ While official national archives work to stabilise a historical and narratological perspective, counter-archival projects like HMV and MoaA point us towards the archive's refractions and instabilities. These films effectively become the archival shadows - the hauntological stutters and excesses that fall outside the official scope of the nation.

\section{Hauntings and Accretions}

Sociologist Avery Gordon's influential conceptualisation of haunting can help us apprehend the heteroglossic shadows of nation and its official records and narratives. Gordon argues that haunting is "a constituent element" of contemporary life. ${ }^{22}$ Rather than signalling absence or disavowal, haunting 
points us towards the "seething presence" that presses against our understanding and experience of history. ${ }^{23}$ As Gordon notes, haunting thickens social life, because it points to the bodies, histories, and multiple forces that endure, despite the efforts to erase them. Such spectral forces speak of how different transparencies of power circulate in late capitalism. A hauntological approach would thus entail engaging with the "affective, historical, and mnemonic structures" of social forces and power relations that are often not seen, but felt. ${ }^{24}$ Taking a lead from Gordon, I argue that we can approach diaspora and diasporic media not (just) in terms of loss and longing, but also as a process of hauntological thickening, especially through examinations of how material densities, narratives, silences, and affects accumulate in the archives.

First, we can consider the material accretions at the surface of the image itself, or what we can term “poor” images. ${ }^{25}$ These textures, like Gordon's historical spectres, densify the present; they accentuate the material imprints that disturb the present, thus challenging an understanding of history as unitary and progressive. Laura U. Marks notes that both film and video "become more haptic as they die." 26 In other words, as they age, analogue formats accumulate material deteriorations, including scratches, colour distortions, bleeds, image ringing/ghosting. Recontextualised through the digital platform, HMV's home videos and MoaA's still images preserve these material markings and, in effect, their swelling accumulations of temporal densities. These densities are reminiscent of Lily Cho's discussion of how diasporic subjectivity coalesces around the imbrication of past and future. Cho offers the insight that "[d]iasporas emerge through losses which have already happened but which also define the future. These losses come both before and after the emergence of diasporic subjectivity." 27 Here, Cho expresses the contradictions of diasporas being shaped by futures that remain haunted by antecedent losses and pasts that perpetually ripple forward. Collapsing tidy narratives of survival and closure, the 
Frames Cinema Journal, Issue 19 (March 2022)

HMV and MoaA archives similarly assemble spectres of past, present, and future that remain unresolvable.

In addition to temporal accretions, HMV's and MoaA's archives also capture the material traces of complex migration histories and transnational entanglements. In her examination of how selfdocumentation has become a constituent element of modern migration and the growing ubiquity of portable recording devices, Alisa Lebow argues that the cinematic has become part and parcel of how we imagine diaspora. ${ }^{28}$ Alongside their transient creators, visual archives migrate across spatial terrains, assembling and resonating histories as they move. For Arjun Appadurai, diasporic public spheres arise when "moving images meet deterritorialized viewers." 29 Materialising through circulations of media, these diasporic public spheres move us decidedly beyond the fixed boundaries of nation. Many of the HMV home movies - captured precisely mid-flight - become the visual appendages accompanying families along protracted transnational journeys. For example, we see the Valcin family move between New York City and Montreal in the late 1960s and early 1970s, before settling in the predominantly Italian suburb of St. Leonard, where they were one of the only Black families in the neighbourhood. ${ }^{30}$ The Burkes, a Jamaican and Guyanese family, are shown with family in Bristol, England, where their father grew up and where their young family lived before moving to Canada in the early 1970s. In another example, the Husain family are shown in Iraq, where they lived shortly between the U.K. and Canada. These particular home videos are archives-in-transit - created, carried, and cared for by families along their journeys across what T. J. Demos might designate as the "psychogeography[ies] of fundamental ambivalence."31 This ambivalence arises precisely from migration as the experience of perpetual oscillation between home and elsewhere, loss and anticipation, severance and settlement. These archives embody the perpetual flux that makes up what 
Avtar Brah calls the "multi-placedness of home" for diasporic peoples, ${ }^{32}$ while also disclosing how these communities are deeply embedded within intricate transnational affiliative and kinship webs.

\section{Quotidian Archives}

Spatial and temporal movements and accretions are also captured by HMV and MoaA's quotidian visual records, which fracture and blur authoritative archival narratives. These quotidian archives become vehicles for hauntological imbrications of the personal, familial, and national. At times, the HMV home videos capture moments with broader historical significance, including the "storm of the century" that dumped over $40 \mathrm{~cm}$ of snow in Montreal during the winter of 1971, captured by the Valcin family; and some of the inaugural occurrences of the Montreal Caribbean Carnival (Carifiesta) during the mid-1970s, captured by the Seaman family. Most of the footage, however, focuses on details of everyday life: family meals, weekends at amusement parks, children's birthday parties, picnics in the park, and a summer backyard barbeque. Similarly, for MoaA, Nguyễn reveals that the "visual deficiency" she encountered in national archives made her "increasingly interested in the everyday routines, daily realities, and struggles of immigrants, particularly in its ordinary context." 33 The images collected through this project include family portraits, social gatherings, and scenes of ordinary life. At the same time, Nguyễn also assembles certain collections to highlight particular underexamined historical narratives, including the images from donor Tatsuo Kage, who in the 1970s migrated to Canada, where he became involved in community organising, especially through the Japanese Canadian Citizens' Association (JCCA). Kage's images document his involvement in the Redress movement, as well as the JCCA protests in support of the Kanehsatake Resistance at Oka in 1990. One of Kage's photographs captures a man at a protest holding a sign that reads, "Greater Vancouver Japanese Canadian Citizens' Assn. Supports Mohawks.” As Liz Park notes, even amidst the media 
deluge coming out of Oka at the time, this single visual document offers significant testimony of "public contestation" and solidarity against the colonial state. ${ }^{34}$

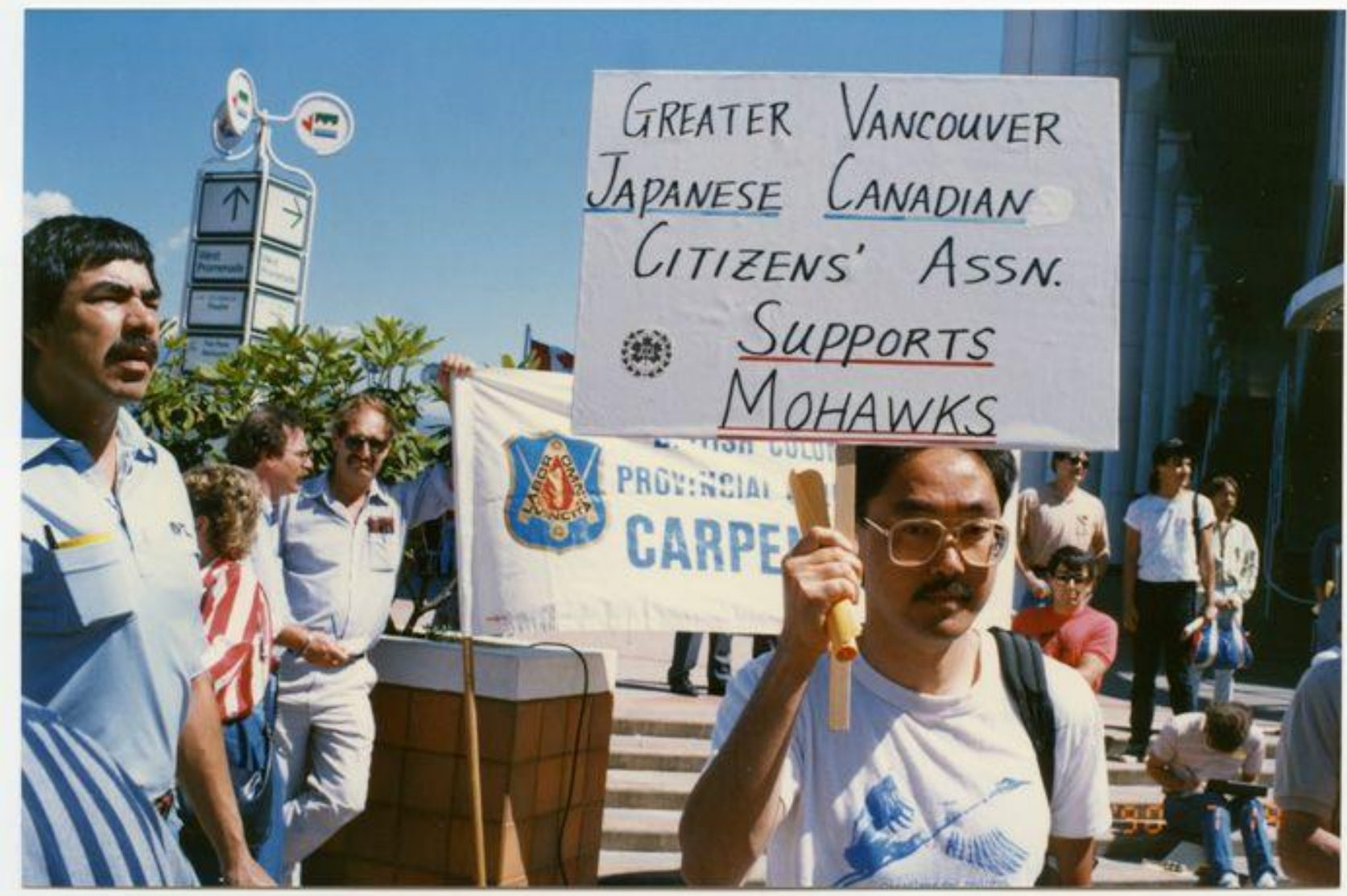

Figure 1: JCCC's protester supports the Mohawks, BC, 1990. Image courtesy of Tatsuo Kage and The Making of an Archive

Kage's photograph is an unassuming visual trace that aids in fleshing out the predominantly overlooked histories of Asian-Indigenous solidarity and activism. It calls to mind Tina Campt's examination of the power of the vernacular - or "less eventful" photographs" - in constructing a politicised "counterimage" of Black diasporic communities. ${ }^{35}$ Taken together, the "less eventful" moments accumulated by HMV and MoaA also speak of the radicality of the unextraordinary, the power of witnessing racialised communities simply moving through the vicissitudes and rhythms of ordinary life. At times, these quotidian scenes also coalesce with broader histories of resistance, affiliation, and survival, even potentially challenging hegemonic visual regimes. Critics argue that 
state multiculturalism is a technology of discipline that functions through the spectacularisation of otherness to maintain whiteness at its unspoken core. ${ }^{36}$ If multiculturalism demands deracinated and commodified difference, or recitals of identity that slot neatly into well-rehearsed categories, we could argue that HMV's and MoaA's archival projects subvert this disciplinary gaze and focus instead on the ephemeral, contradictory, and mundane murmur of everyday life for racialised communities.

While distinctions between state or "top-down" multiculturalism and "bottom up" lived diversity are important, it remains necessary to contend with the ways that these are not always easy to pry apart. As Chinese-Trinidadian-Canadian filmmaker Richard Fung reminds us, the everyday, as captured in home videos, is not an impenetrable sphere, but one rife with the inherited forms and textures of larger ideologies. Fung, whose experimental works often return to and reengage his own home videos, writes about being unsettled when he first "reencountered" some of these archives as an adult, and was struck by how his own Chinese-Trinidadian family had been cast "to the template of suburban America.",37 He notes that home videos reproduce the likeness of the "right family" especially across markers of social class and gender. The family he found reflected back through the celluloid seemed to resemble a heterosexual nuclear family unit as shaped through the creeping influence of US military and consumer culture on the Trinidad \& Tobago of his childhood. ${ }^{38}$ As the HMV and MoaA archives also illustrate, hegemonic forms have the tendency to infiltrate the quotidian, and vice versa.

One of the most fascinating home videos available on the HMV website features the Azure/Chan family, and reveals how the personal, domestic, familial, and national are tightly interwoven. ${ }^{39}$ The Chans are a mixed Chinese and Russian family who lived in the small prairie town of Virden, Manitoba in the 1950s-1960s, when their footage was recorded. Running over twenty minutes in length, this celluloid footage is a collage of scenes that disclose how patriarch George Chan was ostensibly a 
chronicler of both his family and his small town, an amateur filmmaker and an archivist who simultaneously documented personal and collective histories. The sequence opens with a compilation of four different local RCMP (Royal Canadian Mounted Police) weddings which took place in Virden's St Paul's United Church. From here, the footage cuts to an RCMP Christmas dinner held at a local café owned by the Chans. The accompanying text provided by the daughter of the family, Kate, describes how her father, George, developed a relationship with the RCMP, which "helped him maintain his business," the family-run Virden Café. ${ }^{40}$ She also notes that the Chans were the only Chinese family in their small town of Virden, Manitoba, at the time. Following the scene at the Café, George takes his camera on a tour of the town's Christmas lights and decorations, before heading into the Chan home, where the family is celebrating Christmas. The house is decked in a mix of Christmas decorations as well as elaborate Chinese lanterns. The Queen delivers her annual Christmas Message on the television. George's wife, four young Chan children, and an older child from George's first marriage are all present. The family sings carols, opens presents, and sits down to their Christmas dinner. We never catch a glimpse of George, who remains ensconced behind the camera. We are however privy to his cinematographic perspective from behind the camera, his dextrous use of various camera angles and movements and even title cards to set the scene. During the family's Christmas celebrations, George also directs and films his children in a family play, entitled "Fun with Toy," whose plot centres on the children nursing a sick child (a doll) back to health.

The viewer can weave rich narratives from these fleeting glimpses and unspoken subtexts woven into the Chans' home videos. They hint at larger historical tracts - including the Western oil boom, the experience of the sole Asian family in a small Manitoban town in the mid-twentieth century, the role of the RCMP in the colonial settlement of the prairie provinces - which infiltrate seemingly mundane scenes of domestic life. But if these larger narratives of nation bear down on the quotidian, the latter 
also haunts the former by proliferating its shadows and contradictions. As Zimmermann notes, home movies and amateur records challenge the unity of national mythology through the unveiling of recalcitrant histories, fantasies, social relations, and popular memories. ${ }^{41}$ The tapestry of ostensibly minor details in the Chans' home movies - including the family's relationship with the RCMP, the Chan children's silk qipao dresses donned for Christmas - lead one to conjecture about experiences of racial discrimination, the hazards of assimilation, and the ambivalences wrought through cultural hybridity, which may have informed the family's life on the prairies during the mid-20th century. Hence, traces of the quotidian have the potential to densify authoritative records of nation and multiply the latter's spectres.

\section{Accumulated Affects}

Alongside the accretions of the quotidian traces and textures of temporal and spatial transfers, haunting also can be thought of as the thickening of affects that shape our understanding of diasporic archives. Returning to the earlier description of how material losses accumulate on the surface of the poor image, we can examine how noise and glitches introduce opacities into the otherwise smooth image and interrupt the ease or facility with which diasporic archival images are made available to their audiences. However, such losses can also affectively impel us. Imperfect visual access, for Marks, prompts a haptic engagement that can usurp visual mastery, which Marks describes as the process through which the other is "killed into knowledge."42 Haptic engagement is a mode that implicates the whole body in the act of perceiving. The quality of low-fidelity formats like video preserves the impenetrability of the image, so that the eye is moved to skim across surfaces as opposed to "plung[ing] into depth.",43 This more reciprocal embodied relation with the image leaves the object of knowledge, or the "other," intact. At the same time, the ungraspability of the poor image propels the viewer to intend everforward, thus dissolving sensorial and bodily boundaries in a co-implication of intimacies: "[i]n a 
haptic relationship our self rushes up to the surface to interact with another surface." ${ }^{44}$ This subversion of power relations - evanescent as it may be - is, for Marks, the crux of the haptic as a generative mode of being and knowing, especially for minoritised communities.

Alongside the denial of visual transparency through poor images, the home movies collected through HMV also prevent the viewer from complete narrative access. In the absence of narrative structuring, the audience pieces together clues from fragments of quotidian ephemera. The descriptive texts offered alongside the archives provides some framework for decipherment, but they also leave much unsaid. For example, the Baksh family videos include a two-minute clip entitled "Road Trip" (2008). It is time-lapse footage of a car ride between the Scarborough and North York suburbs of Toronto shot on Super 8. Shenaz Baksh has mounted the camera on the dashboard of the car, first trained on her aunt in the passenger seat. After her aunt exits the car at some point along the journey, Shenaz points the camera at herself as she drives to pick up her next passenger, her father. When he enters the car, she again readjusts the camera to focus on him now. Her father does not speak, but looks straight at the road ahead, sometimes rubbing his chin, seemingly deep in thought. We read consternation on his face. Regarding this segment of the footage, the accompanying text simply reads: "[t]he camera is later refocused on her father in the passenger seat, as she drives him to his chemotherapy session. For the last portion of the road trip, Shenaz turns the camera onto the road itself, finally parking in front of her home where she began." ${ }^{45}$ We perhaps lose details and information in the quickened pace and dropped frames of time-lapse; but this acceleration also condenses time and meaning. Here, it saturates the short sequence with inferred meanings and a silence that hangs in the air dense with affect. Such silences are markers of counter-archives, which denounce the authoritative archive's aims of completion and objectivity. They also compel their audiences by extending a space for our affective and sensorial participation. 
Frames Cinema Journal, Issue 19 (March 2022)

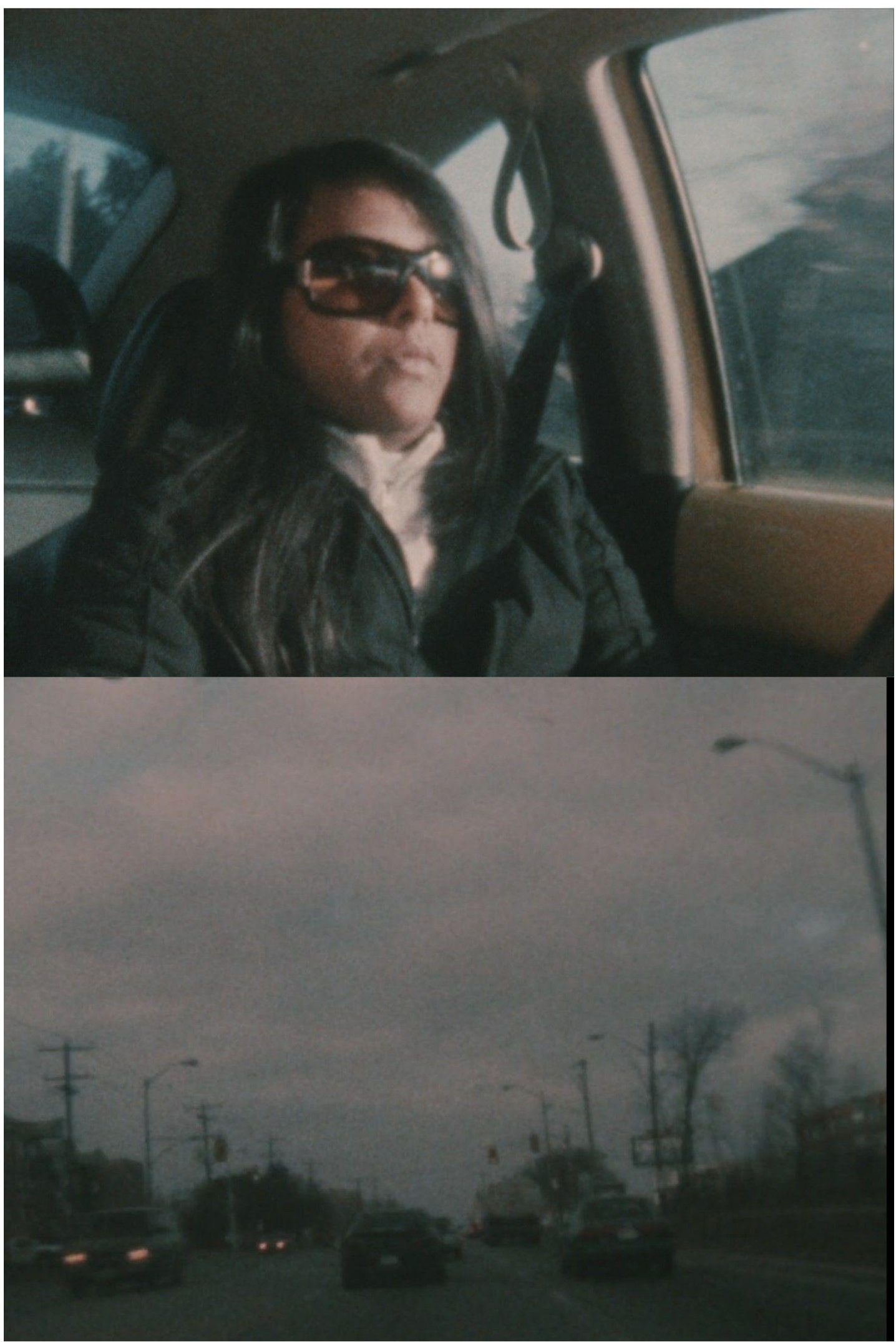

Figure 2 and 3: Stills from Baksh Family Road Trip, 2008. Image courtesy of Shenaz Baksh and Home Made Visible. 
Both HMV and MoaA seem to serve a therapeutic function organised around the aim to rectify the exclusions of official archives through processes of community engaged archival affirmations. These include the creation of collective spaces for participants to remember, share personal and familial memories, as well as exercise some form of agency over how these remembrances are then preserved and reanimated. For diasporic audiences, access to these home videos of others can also be therapeutic. The digital platform allows encounters with others' once-private scenes of domestic life, and also becomes a site of affective engagement, knowledge production, and communal recognition. As Appadurai notes, interactive media can help construct and mobilise diasporic public spheres through acts of "reading together" that have the potential to be more meaningfully participatory than those elucidated in Benedict Anderson's now-fraught model of "imagined communities."46 The quotidian archives agglomerated through HMV and MoaA form flexible communities of shared intimacies, incorporating material traces of life that seem familiar, and might fill the lacunae in the audiences' own memories. However, rather than filling up archival gaps and silences, both HMV and MoaA instead linger on them, even drawing them out.

Extending Laura Wexler's idea that photographs are a "record of choices," Tina Campt argues that they are also "records of intentions." 47 The notion of intentionality requires us to consider "the social, cultural, and historical relationships figured in the image, as well as a larger set of relationships outside and beyond the frame - relationships we might think of as the social life of the photo."48 We can therefore think of these images as records of affects that extend far beyond the images themselves. They are documents containing residues of feelings half observed, half repressed. They also beg questions around the affective charge of their capture - about what exactly prompted their makers' desire to document. Many of the photographs from MoaA invite these queries. One image captures a young man, perhaps in his 20 s, posed casually in a shirt and trousers, leaning by a sign that reads 
"Philippine Refugee Processing Centre: Freedom Plaza." Another image shows a small child in a mushroom cut perched atop a gleaming Ford Torino, gazing slightly quizzically off camera, as if awaiting a cue from a nearby adult. In yet another photo, a teenager in sunglasses flashes a grin at the camera with one arm resting on a towering store mannequin donning an RCMP uniform. These are likely snapshots of people caught in the throes of arrival/departure/settlement, the act of documenting perhaps urged by the need to momentarily stabilise the tenuousness of being on the threshold. Appadurai claims that citizenship in modern nation-states hinges on a "tight fit between plot and character (or story and actor, or narrative and identity)," and that state mechanisms provide the "territorial ground for stabilising and connecting plot and character in verifying legitimate citizens.",49 This suggests that plot and character are subsequently de-synchronised for migrant communities, such that the narrative and emotional scaffoldings that furnish one's sense of "territorial, personal, and sanguinary stability" are uprooted. ${ }^{50}$ Diasporic archives such as those captured by HMV and MoaA can thus be understood as communities' inscriptions of narratives of historical and affective emplacement for themselves, especially in the absence of state-sanctioned technologies of narratological confirmation.

Subsequent decisions regarding whether or not to digitise and make these archives publicly available are no doubt equally affectively laden. In other words, these records gathered by MoaA and HMV all bear affective imprints - the often tacit emotional and textural modalities that are especially recognisable to others who have experienced dislocation. These imprints echo the accretions of traumas and melancholies that diasporic subjects inherit and bear with them - disturbances which Shantel Martinez refers to as the "generational hauntings" that "imprint" the body. ${ }^{51}$ We can think of these as the dense narratives of arrival, loss, settlement, and survival that accrue along migratory journeys. The accumulated after-effects of dispersal and displacement thus mark this trove with a 
Frames Cinema Journal, Issue 19 (March 2022)

hauntological stain. As Lily Cho describes, diaspora rests not on definitional stability but on subjective experiences of unarticulated losses: "Diaspora is not a function of socio-historical and disciplinary phenomena, but emerges from deeply subjective processes of racial memory, of grieving for losses which cannot always be articulated and longings which hang at the edge of possibility. It is constituted in the spectrality of sorrow and the pleasures of 'obscure miracles of connection." 52 These “condition[s] of subjectivity" can form a relational nexus for diasporic audiences, who might arrive at these archives with a ready store of their own emotional histories enfolded upon the body, and who, through the refraction of these histories, might recognise a familiar glance, silence, or gesture in the cacophony of the quotidian.

\section{Conclusion}

As populations become increasingly transient, so too are the accumulated images that accompany their movements dislodged from any unitary or stable point of origin. Participatory diasporic archives like HMV and MoaA provide vehicles to, at least momentarily, encapsulate and stabilise material, temporal, and spatial movements and accretions, while at the same time allowing for quotidian histories to be recirculated, and put into emergent orbits. Focusing on these two archival projects, this paper has explored how diasporic archives can challenge and redress the elisions and exclusions in official records, especially by capturing the ephemeral and quotidian to push back against multiculturalism's regimes of visibility. MoaA and HMV are projects that aim to gather and hold space for the still and moving image archives produced through migrations and dislocations. They have gathered a significant trove of archival materials from minoritised communities and mobilised them in an effort to insert overlooked images, narratives, and histories into public imaginaries. At the same time, one could argue that both projects also point to the impossibility of this task, or that gaps and elisions themselves paradoxically become the structuring force of the archival project, as well as 
counter-archival endeavours of collecting and accounting for occluded histories. This is why approaching diasporic archives through the orientation of hauntological thickening might prove useful, for it allows us to think beyond loss and trauma to the ambivalent accumulations of discourses, temporalities, and affects that bear down on the everyday. It allows us to not just come up against absence, but to reorient around an understanding of absences as potentially replete.

\section{Notes}

1 “About the Making of an Archive website," The Making of an Archive, accessed November 20, 2021, http://themakingofanarchive.com/about/\#faq.

${ }^{2}$ Nguyễn describes how she was prompted to embark on this project partly because of how difficult it was to find actual images of the multiculturalism touted by Canada in its archives, including the Libraries and Archives Canada, the National Film Board, the Canadian Broadcasting Corporation. Rachel Sanders, "She didn't find much multiculturalism in Canada's official archives - so she made her own," $C B C$, October 17, 2017. https://www.cbc.ca/arts/she-didn-t-find-much-multiculturalism-in-canada-s-official-archives-so-shemade-her-own-1.4358628.

${ }^{3}$ HMV organizers note that it was a challenge acquiring Indigenous submissions, partly due to the fact that outreach was done through Regent Park Film Festival's existing networks, and the Festival serves predominantly Black and other racialised communities. See "Project Report," Home Made Visible, accessed November 20, 2021, http://homemadevisible.ca/wp-content/uploads/2020/05/HMV-Project-Report.pdf. There are some home movies donated by Indigenous families to the project, but none of these are available on the HMV website, as yet.

${ }^{4}$ Parastoo Anoushahpour, Faraz Anoushahpour Nadine Arpin, Maya Bastian, Jennifer Dysart, Aeyliya Husain, Lisa Jodoin, and Melisse Watson were the artists commissioned by HMV.

${ }^{5}$ At the time of this writing, there are fifteen families whose home videos are available on the HMV website. As noted by project archivist, Katrina Cohen-Palacios, the choice regarding access was up to the individual donors and families. In Cohen-Palacios, "Home Made Visible: Partnering with a Film Festival to Preserve IBPOC Home Movies," Archives Association of Ontario Conference: Building Bridges, Connecting Communities, October 2020. http://hdl.handle.net/10315/38531.

${ }^{6}$ Nguyễn also produced an artists' book as part of this project: Jacqueline Hoàng Nguyễn, Vanessa Kwan, and Dan Pon, eds., The Making of An Archive (Vancouver: grunt gallery, 2018).

${ }^{7}$ Adele Perry, "The Colonial Archive on Trial: Possession, Dispossession, and History in Delgamuukw v. British Columbia," Archive Stories: Facts, Fictions, and the Writing of History (Durham, NC: Duke University Press, 2005).

${ }^{8}$ Brett Kashmere, "Cache Rules Everything Around Me," Incite! Journal of Experimental Media and Radical Aesthetics 2 (2010), accessed November 15, 2021. http://www.incite-online.net/intro2.html.

${ }^{9}$ Paula Amad, Counter-Archive: Film, the Everyday, and Albert Kahn's Archives de la Planète (New York, NY: Columbia University Press, 2010), 4. 
${ }^{10}$ Kashmere, "Cache Rules Everything."

${ }^{11}$ MoaA was funded by Canada Council for the Arts, as well as Södertälje kommun, a municipal fund. HMV was funded by the Toronto Arts Council, and Canada Council for the Arts's New Chapter grant, a one-time grant program commemorating the 150th anniversary of Confederation in 2017.

${ }^{12}$ Patricia R. Zimmermann, Reel Families: A Social History of Amateur Film (Bloomington \& Indianapolis, IN: Indiana University Press, 1995).

${ }^{13}$ I am tracing the enshrinement of Canadian multiculturalism to the Royal Commission on Bilingualism and Biculturalism established in 1963. Other important milestones leading up to the official adoption of the Canadian Multiculturalism Act by Parliament in 1988 include: the transition from an overtly racist immigration policy to the Immigration Points System (1967), Prime Minister Justin Trudeau's declaration of Canada as a multicultural nation within the bilingual framework (1971), and the inclusion of multiculturalism in the Canadian Charter of Rights and Freedoms (1982).

${ }^{14}$ See for example Eve Haque, Multiculturalism Within a Bilingual Framework; Sunera Thobani, Exalted Subjects: Studies in the Making of Race and Nation in Canada (Toronto: University of Toronto Press, 2007); Himani Bannerji, The Dark Side of the Nation: Essays on Multiculturalism, Nationalism, and Gender (Toronto: Canadian Scholars' Press Inc, 2000).

15 "Isaac Family - Sacré-Coeur Christmas Concert (2004)," Home Made Visible, accessed November 20, 2021, http://homemadevisible.ca/home-movie/isaac-family-sacre-coeur-christmas-concert-2004/.

16 “Truong/Tram Family - 1 Month old Birthday (1992)," Home Made Visible, accessed November 20, 2021, http://homemadevisible.ca/home-movie/trinh-nha-truong-6-2-of-3/.

17 "About the Making of an Archive," The Making of an Archive.

${ }^{18}$ Ibid.

${ }^{19}$ Patricia R. Zimmermann, "Morphing History into Histories: From Amateur Film to the Archive of the Future," The Moving Image: The Journal of the Association of Moving Image Archivists 1.1 (2001): 110.

${ }^{20}$ Zimmermann, "Morphing History," 110.

${ }^{21}$ Zimmermann, "Morphing History," 127.

${ }^{22}$ Avery F. Gordon, Ghostly Matters: Haunting and the Sociological Imagination (Minneapolis, MN:

University of Minnesota Press, 2008), 7.

${ }^{23}$ Gordon, Ghostly Matters, 8.

${ }^{24}$ Gordon, Ghostly Matters, 18.

${ }^{25}$ See Hito Steyerl, "In Defense of the Poor Image," e-flux 10 (2009), accessed January 15, 2021. https://www.e-flux.com/journal/10/61362/in-defense-of-the-poor-image/.

${ }^{26}$ Laura U. Marks. The Skin of the Film: Intercultural Cinema, Embodiment, and the Senses (Durham, NC: Duke University Press, 2000), 172.

${ }^{27}$ Lily Cho, "The Turn to Diaspora," TOPIA 17 (2918): 17.

${ }^{28}$ Alisa Lebow, "The Camera as Peripatetic Migration Machine," Cinema of Me: The Self and Subjectivity in First Person Documentary, ed. Alisa Lebow (London: Wallflower Press, 2012), 219-232, 230-1.

${ }^{29}$ Arjun Appadurai, Modernity at Large: Cultural Dimensions of Globalization (Minneapolis, MN \& London: University of Minnesota Press, 1996), 4.

${ }^{30}$ The Valcin family's home videos were donated by filmmaker Nadine Valcin, who is shown as a young child in the videos.

${ }^{31}$ T. J. Demos, The Migrant Image: The Art and Politics of Documentary during Global Crisis (Durham, NC \& London: Duke University Press, 2013), 4.

${ }^{32}$ Avtar Brah, Cartographies of Diaspora: Contesting Identities (New York, NY: Routledge, 1996), 197.

33 "About," The Making of an Archive.

${ }^{34}$ Liz Park, "The Telling Details in Jacqueline Hoàng Nguyễn's The Making of An Archive," The Making of An Archive, ed. Jacqueline Hoàng Nguyễn, Vanessa Kwan, Dan Pon (Vancouver: grunt gallery, 2018), 29-30.

${ }^{35}$ Tina Campt, Image Matters: Archive, Photography, and the African Diaspora in Europe (Durham, NC and London: Duke University Press, 2012), 6-8. See also Brian Wallis argument about the political function of 
African American vernacular photography in Brian Wallis and Deborah Willis, African American Vernacular Photography: Selections from the Daniel Cowin Collection (New York, NY: International Center of Photography, 2005).

${ }^{36}$ See for example Bannerji, The Dark Side of the Nation; Ghassen Hage, "Republicanism, Multiculturalism, Zoology," Communal Plural 2 (1993): 113-37.

${ }^{37}$ Richard Fung, "Remaking Home Movies," Mining Home Movies: Excavations into Historical and Cultural Memories, ed. Karen L. Ishizuka and Patricia R. Zimmermann (Berkeley, CA: University of California Press, 2008), 33.

${ }^{38}$ Ibid.

${ }^{39}$ The Chan family videos are labelled as a contribution from the "Azure family" on the HMV website, presumably after the donor, Kate Azure.

40 “Azure Family - RCMP Wedding \& Christmas (1962)," Home Made Visible, accessed November 29, 2021, http://homemadevisible.ca/home-movie/azure-family-rcmp-wedding-christmas-1962/.

${ }^{41}$ Zimmermann, "Introduction. The Home Movie Movement: Excavations, Artifacts, Minings," Mining Home Movies: Excavations into Historical and Cultural Memories, ed. Karen L. Ishizuka and Patricia R.

Zimmermann (Berkeley, CA: University of California Press, 2008).

${ }^{42}$ Marks, The Skin of the Film, 193.

${ }^{43}$ Marks, Touch: Sensuous Theory and Multisensory Media (Minneapolis, MN \& London: University of Minnesota Press, 2002), 8.

${ }^{44}$ Marks, Touch, xvi

45 "Baksh family - Road Trip (2008)," Home Made Visible, accessed November 29, 2021, http://homemadevisible.ca/home-movie/shenaz-baksh-family-road-trip/.

${ }^{46}$ Appadurai, "Traumatic Exit, Identity Narratives, and the Ethics of Hospitality," Television \& New Media 20.6 (2019): 562.

${ }^{47}$ Campt, Image Matters, 6.

${ }^{48}$ Ibid.

${ }^{49}$ Appadurai, "Traumatic Exit," 563.

${ }^{50}$ Ibid.

${ }^{51}$ Shantel Martinez, "(Re)Animated Pasts: Diasporic Visions of Longing and Belonging," Qualitative Inquiry 22.4 (2016): 281.

${ }^{52}$ Cho, "The Turn to Diaspora," 15.

\section{Bibliography}

Amad, Paula. Counter-Archive: Film, the Everyday, and Albert Kahn's Archives de la Planète. New York, NY: Columbia University Press, 2010.

Appadurai, Arjun. Modernity at Large: Cultural Dimensions of Globalization. Minneapolis, MN \& London: University of Minnesota Press, 1996.

---. "Traumatic Exit, Identity Narratives, and the Ethics of Hospitality," Television \& New 
Media 20, no. 6 (2019): 558-565.

Bannerji, Himani. The Dark Side of the Nation: Essays on Multiculturalism, Nationalism, and Gender. Toronto: Canadian Scholars’ Press Inc, 2000.

Brah, Avtar. Cartographies of Diaspora: Contesting Identities. New York, NY: Routledge, 1996. Campt, Tina. Image Matters: Archive, Photography, and the African Diaspora in Europe Durham, NC and London: Duke University Press, 2012.

Cho, Lily. "The Turn to Diaspora.” TOPIA 17 (2018): 11-30.

Cohen-Palacios, Katrina. "Home Made Visible: Partnering with a Film Festival to Preserve IBPOC Home Movies," Archives Association of Ontario Conference: Building Bridges, Connecting Communities, October 2020. Accessed November 20, 2021. http://hdl.handle.net/10315/38531.

Demos, T.J. The Migrant Image: The Art and Politics of Documentary during Global Crisis.

Durham, NC \& London: Duke University Press, 2013.

Fung, Richard. "Remaking Home Movies.” In Mining Home Movies: Excavations into Historical and Cultural Memories, edited by Karen L. Ishizuka and Patricia R. Zimmermann, 29-40. Berkeley, CA: University of California Press, 2008.

Gordon, Avery. Ghostly Matters: Haunting and the Sociological Imagination. Minneapolis, MN: University of Minnesota Press, 1997.

Hage, Ghassen. "Republicanism, Multiculturalism, Zoology," Communal/Plural 2 (1993): 11337.

Haque, Eve. Multiculturalism Within a Bilingual Framework: Language, Race, and Belonging in Canada. Toronto: University of Toronto Press, 2013.

Home Made Visible. Accessed November 20, 2021. http://homemadevisible.ca/ 
Huyssen, Andreas. "Diaspora and Nation: Migration into Other Pasts," New German Critique 88 (Winter 2003): 147-164.

Kashmere, Brett. "Cache Rules Everything Around Me," Incite! Journal of Experimental Media and Radical Aesthetics 2 (2010), http://www.incite-online.net/intro2.html.

Lebow, Alisa. "The Camera as Peripatetic Migration Machine.” In Cinema of Me: The Self and Subjectivity in First Person Documentary, edited by Alisa Lebow, 219-232. London: Wallflower Press, 2012.

Marks, Laura U. The Skin of the Film: Intercultural Cinema, Embodiment, and the Senses Durham, NC: Duke University Press, 2000.

---. "Video haptics and erotics," Screen 39.4 (1998): 331-348.

Martinez, Shantel. “(Re)Animated Pasts: Diasporic Visions of Longing and Belonging," Qualitative Inquiry 22, no. 4 (2016): 280-86.

Nguyễn, Jacqueline Hoàng, Vanessa Kwan, and Dan Pon, eds., The Making of An Archive. Vancouver: grunt gallery, 2018.

Park, Liz. “The Telling Details in Jacqueline Hoàng Nguyễn's The Making of An Archive.” In The Making of An Archive, edited by Jacqueline Hoàng Nguyễn, Vanessa Kwan, and Dan Pon, 1945. Vancouver: grunt gallery, 2018.

Perry, Adele. "The Colonial Archive on Trial: Possession, Dispossession, and History in Delgamuukw v. British Columbia." In Archive Stories: Facts, Fictions, and the Writing of History, edited by Antoinette Burton, 325-350. Durham, NC: Duke University Press, 2005. Steyerl, Hito. "In Defense of the Poor Image," e-flux 10 (2009). https://www.eflux.com/journal/10/61362/in-defense-of-the-poor-image/. 
Stoler, Ann Laura. "Imperial Debris: Reflections on Ruins and Ruination," Cultural Anthropology 23, no. 2 (2008): 191-219.

The Making of an Archive. "About the Making of an Archive website.” Accessed November 20, 2021. http://themakingofanarchive.com/about/\#faq.

Thobani, Sunera. Exalted Subjects: Studies in the Making of Race and Nation in Canada Toronto: University of Toronto Press, 2007.

Wallis, Brian, and Deborah Willis. African American Vernacular Photography: Selections from the Daniel Cowin Collection. New York, NY: International Center of Photography, 2005.

Zimmermann, Patricia R. "Introduction. The Home Movie Movement: Excavations, Artifacts, Minings." In Mining Home Movies: Excavations into Historical and Cultural Memories, edited by Karen L. Ishizuka and Patricia R. Zimmermann, 1-28. Berkeley, CA: University of California Press, 2008.

---. "Morphing History into Histories: From Amateur Film to the Archive of the Future," The Moving Image: The Journal of the Association of Moving Image Archivists 1, no. 1 (2001): 108-130. ---. Reel Families: A Social History of Amateur Film. Bloomington \& Indianapolis, IN: Indiana University Press, 1995.

\section{Author Biography}

May Chew is an Assistant Professor at the Mel Hoppenheim School of Cinema and Department of Art History at Concordia University. Her current research focuses on diasporic media and archives, haunting, decolonial aesthetics, and critical genealogies of immersion. Her work appears in Imaginations, the International Journal of Heritage Studies, the Journal of Canadian Art History, and 
Frames Cinema Journal, Issue 19 (March 2022)

an issue of the journal PUBLIC on the theme of "Archives/Counter-Archives," which she co-edited with Janine Marchessault and Susan Lord. She also collaborates on Ethnocultural Art Histories Research in Media, Worlding Public Cultures and Archive/Counter-Archive. 